\title{
Treatment of Infantile hemangioma by ND YAG laser.
}

\author{
Yasser A. Hamed MD* Maha M. Sultan, MD** Fatma M. Abd Al-Salam, MD** \\ * Department of Dermatology and venereology; Faculty of Medicine Al-Azhar \\ University **Department of Dermatology and venereology; Faculty of Medicine for \\ Girls, Al-Azhar University
}

\begin{abstract}
:
Hemangiomas one of the most common type of congenital anomaly in childhood. Although many resolve spontaneously but intervenation is required when their growth could damage vital adjacent structure. It is characterized by an initial phase of rapid proliferation followed by slow involution, often leading to complete regression. Many therapeutic approaches for hemangiomas with different types of laser such as CO2 laser PDL, KTP and ND-YAG laser have been used.The aim of this study is to determined the efficacy of Nd YAG laser in the treatment of infantile hemangiomas.

PATIENTS \& Methods:This study include 18 patients aged 3 months to 2 years with cutaneous hemangiomas were treated with a Nd: YAG laser. The laser power was between 2630 joules with a pulse length $50 \mathrm{ml}$ second. The lesion was cooled with dynamic cooling device (DCD) $30 \mathrm{ml}$ second prior plus shots.The number of sessions was ranged from 4 to 12 sessions with two weeks interval.

Results:After 6 months of follow-up of laser treatment, excellent response was seen in 6 patients $(33.3 \%)$, very good response was seen 6 patients $(33.3 \%)$, good response was seen in 5 patients $(27.77 \%)$, and poor response was seen in 1 patient ( $5.55 \%)$. Complications were seen in 3 patients 1 with bleeding and 2 with scar.

Conclusions:Nd: YAG laser irradiation produces good cosmetic results for the treatment of cutaneous hemangiomas in Egyptian infants.

Keywords: Hemangioma\& ND YAG laser
\end{abstract}

\section{Introduction}

A hemangioma is a benign congenital vascular malformation and the most common type of tumour in infancy, affecting up to $12 \%$ of all children by 1 year of age.( Batta, et al.,. 2002)

There is a female predominance with 3: 1 ratio compared to affected males (Chiller et al., 2002). They are usually absent at birth but appear and enlarge during the first 6 months of life and often continue to grow until 12 months of age (Vlachakis, et al.,..2003).

Hemangiomas manifest as red raised and bosselated swellings (Esterly, 1992), the majority of them appear as a single lesion, with head and neck predominance(Clymer, 1998).

Hemangiomas can be described as superficial, deep or combined .It can also be classified into capillary, cavernous and "Capillary cavernous" based on their depths in the dermis and subcutaneous fat (Finn, ,et al,1983). Complications of hemangiomas appear such as ulceration (Kim et al., 2001):, bleeding (Boussemart, et al 1995), scarring (Chan et al 2002) infection (Yagupsky, 1987) and involvement of important functions such as vision (Kushner, 1990), respiration (Orlow et al .1997), hearing or feeding along with cosmetic disfigurement, are clear indications for treatment (Landthaler,et al 1995).

Various therapeutic options for treatment of hemangiomas include, cryosurgery (Castro -Ron 1985), sclerotherapy (Staindl , 1989)., intralesional steroid therapy(Carruther et al and prendivillej. (1998), surgical excision (Chang, et al,1998) .and laser as $\mathrm{CO} 2$ laser PDL, KTP and ND-YAG laser (Landthaler \&Hohenleutner 2001)

The objective of this study was to determine of the efficacy of Nd YAG photo coagulation as definitive treatment of hemangiomas in the Egyptian infants as it has longer wave length and penetrates deeply in the tissue and it is suitable for Egyptian skin type. 


\section{Patients\&Methods:-}

This study include 18 patients with cutaneous hemangiomas were treated with Nd YAG laser (gentel YAG candela corp, USA). 13 patients ( $72.22 \%$ )were females and 5 patients $(27.77 \%$ ) were males and their ages ranged from 3 months to 2 years. All cases of hemangiomas were diagnosed clinically. The anatomic location of the hemangiomas varied such as nose (1 patient) ,cheek ( 9 patients) ,forehead (1 patient), neck (5 patients), upper lip (1 patient), and forearm (1 patient). All the patients in this study did not receive any other treatments such as steroids. Preoperative evaluation in all patients included medical history, a complete physical examination, and blood count (i.e. hamatocrit, and, platelet count). The indications for treatment were cosmetic disfigurement (16 patients) and affection of vital function as respiration and feeding (2 patients). Each hemangioma was categorized after measuring its length, width, and height. On the basis of area (Length $\mathrm{X}$ width) they were divided (classified) into three categories :- (a) 1 -2 $\mathrm{cm}^{2}$ (b) $2-4 \mathrm{~cm}^{2}$ (c) $<4 \mathrm{~cm}^{2}$ on the basis of height, they were divided into three categories (A) $1-2 \mathrm{~cm} \quad$ (B) $2-3 \mathrm{~cm}(\mathrm{C})<3$ $\mathrm{cm}$ (Table 1).

\begin{tabular}{|c|c|c|c|c|}
\hline & \multicolumn{4}{|c|}{ Height } \\
\hline Area & & A $(1-2 \mathrm{~cm})$ & B $(2-3 \mathrm{~cm})$ & $C(>3 \mathrm{~cm})$ \\
\hline & $a\left(1-2 \mathrm{~cm}^{2}\right)$ & & & \\
\hline & b $\left(2-4 \mathrm{~cm}^{2}\right)$ & & & \\
\hline & c $\left(>4 \mathrm{~cm}^{2}\right)$ & & & \\
\hline
\end{tabular}

All patients were treated without local or general anesthesia. The laser was performed in double passes manner with the hand-Piece of the irradiation of delivery system, being held perpendicular to the skin with the lesion at its focal point. The laser power was between 26-30 joules with a pulse length of $50 \mathrm{ml}$ seconds. Laser energy was delivered to all areas of the vascular lesion. The average time for the laser photocoagulation procedure varied from 2 to 3 minutes depending on extent of the lesion. Dynamic cooling device (DCD) was used for $30 \mathrm{ml}$ seconds prior to pulse shots In all cases the patients wore protective eye covering .A topical application of antibiotic ointment was given for the treated areas. The number of sessions ranged from 4 to 12 sessions with two weeks interval. 


\section{Results}

The treatment results were assessed by measuring the change in size of the lesion, and were classified as following: " Excellent" 90-100 \% area reduction, "Good" 50-89\% area reduction, "Moderate"

$20-49 \%$ area reduction and "Poor" $0-19 \%$ area reduction. Complications were seen in 3 patients one with bleeding and two with scar. (see Table 2) (Fig. 1\&2).

(Table 2): Response of Nd YAG laser therapy as regard area of hemangiomas

\begin{tabular}{|c|c|c|c|c|c|}
\hline Results & \multicolumn{5}{|c|}{ Height } \\
\hline & & & A & B & $\mathrm{C}$ \\
\hline & & & $(1-2 \mathrm{~cm})$ & $(2-3 \mathrm{~cm})$ & $(>3 \mathrm{~cm})$ \\
\hline & $\mathbf{a}$ & $\left(1-2 \mathrm{~cm}^{2}\right)$ & & & \\
\hline & & Excellent & 2 & & \\
\hline & & Very good & & 1 & \\
\hline & b & $\left(2-4 \mathrm{~cm}^{2}\right)$ & & & \\
\hline & & Excellent & 4 & & \\
\hline & & Very good & & 5 & \\
\hline Area & & Good & & & 1 \\
\hline & & Moderate & & & \\
\hline & & Poor & & & \\
\hline & c & $\left(>4 \mathrm{~cm}^{2}\right)$ & & & \\
\hline & & Moderate & & & \\
\hline & & Good & 2 & 2 & \\
\hline & & Poor & & & 1 \\
\hline
\end{tabular}


Treatment of Infantile hemangioma by.....

Table (3) :Response of ND YAG laser therapy and side effects as regard patients age, sex, sites of lesion,and number of sessions.

\begin{tabular}{|c|c|c|c|c|c|c|}
\hline NUMBER & AGE & SEX & SITE & SESSIONS & $\begin{array}{c}\text { SIDE } \\
\text { EFFECTS }\end{array}$ & RESPONSE \\
\hline 1 & 3 & $\mathrm{~F}$ & NECK & 12 & BLEEDING & V GOOD \\
\hline 2 & 12 & M & Cheek & 8 & & GOOD \\
\hline 3 & 3 & $\mathrm{~F}$ & FORHEAD & 4 & & $\mathrm{BAD}$ \\
\hline 4 & 12 & $\mathrm{~F}$ & Cheek & 5 & & EXCELLENT \\
\hline 5 & 14 & $\mathrm{~F}$ & Cheek & 4 & & V GOOD \\
\hline 6 & 8 & M & Cheek & 7 & & EXCELLENT \\
\hline 7 & 8 & $\mathrm{~F}$ & UPPER LIP & 12 & scar & V GOOD \\
\hline 8 & 5 & $\mathrm{~F}$ & Cheek & 9 & & GOOD \\
\hline 9 & 3 & $\mathrm{~F}$ & NECK & 11 & & V GOOD \\
\hline 10 & 17 & $\mathrm{~F}$ & NECK & 6 & & EXCELLENT \\
\hline 11 & 6 & $\mathrm{~F}$ & Cheek & 6 & & GOOD \\
\hline 12 & 3 & M & FOREARM & 8 & & V GOOD \\
\hline 13 & 12 & M & Cheek & 8 & & EXCELLENT \\
\hline 14 & 24 & $\mathrm{~F}$ & NECK & 4 & & GOOD \\
\hline 15 & 6 & M & Cheek & 5 & & EXCELLENT \\
\hline 16 & 7 & $\mathrm{~F}$ & NECK & 7 & & V GOOD \\
\hline 17 & 24 & $\mathrm{~F}$ & Cheek & 4 & & GOOD \\
\hline 18 & 5 & $\mathrm{~F}$ & TIP OF NOSE & 12 & scar & EXCELLENT \\
\hline Mean & 9.56 & & & 7.33 & & \\
\hline SD & 6.69 & & & 2.89 & & \\
\hline Min & 3 & & & 4 & & \\
\hline Max & 24 & & & 12 & & \\
\hline
\end{tabular}




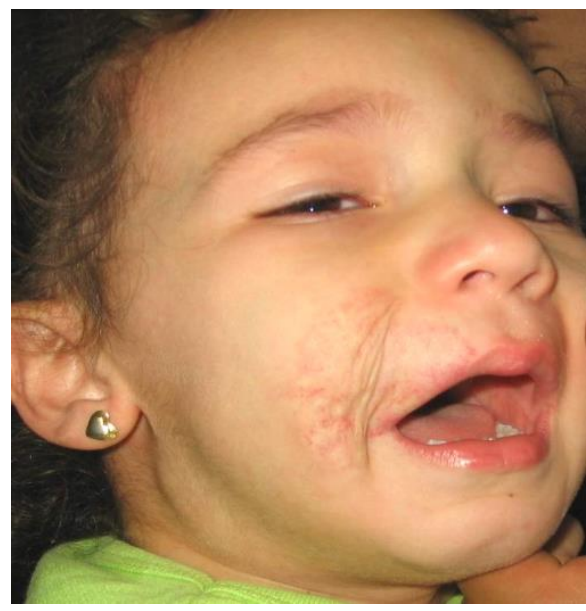

Figure (1)Hemangioma of RT check \&upper lip about $4 X 2 \mathrm{~cm}$ before laser therapy

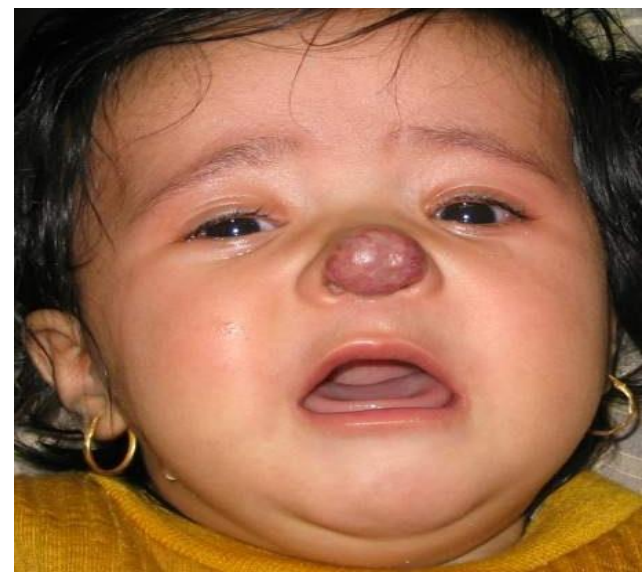

Figure (2) Hemangioma on the tip of the nose

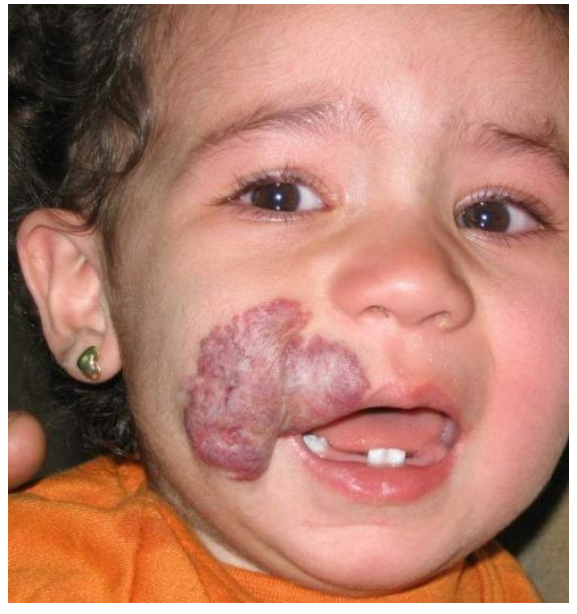

Patient after 12 sessions with excellent response

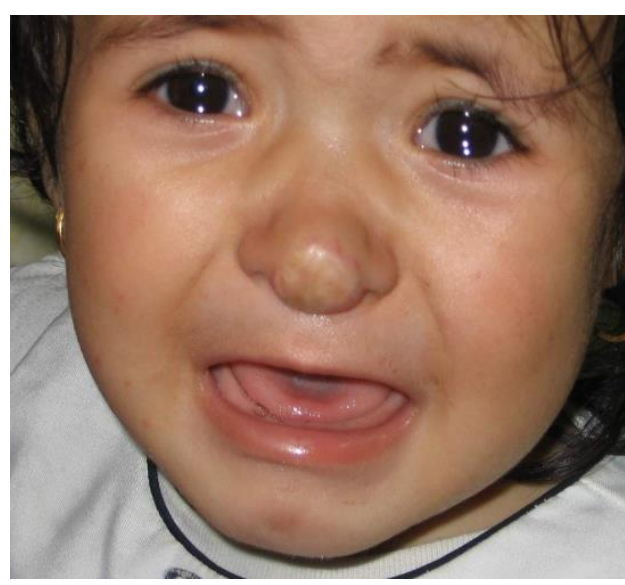

After 12 sessions with excellent response 


\section{Discussion}

A number of treatment modalities have been proposed for the treatment of hemangiomas, including: systemic therapy with corticosteroids, interferon- $\alpha 2 \mathrm{a}$, surgical procedures, compression, sclerosis treatment, embolization, intralesional injection of corticosteroids, and cryotherapy. One of the most significant advances in the treatment of hemangiomas has been the advent of laser technology (Vlachakis, et al.,.2003).

There are many reports of the treatment of hemangioma using different types of laser, including the argon, $\mathrm{CO} 2$, the Nd:YAG laser, the flash lamp-pumped pulsed dye laser (FPDL) and more recently the longpulsed tunable dye laser (LPTDL)

\section{(Landthaler\& Hohenleutner 2001).}

We have chosen the Nd:YAG laser as a therapeutic modality because its beam penetrates approximately $8 \mathrm{~nm}$ into soft tissue, and the scattering in the tissue produce deep photocoagulation.It also suitable for Egyptian skin type .Our use of Nd YAG laser produced excellent clinical and cosmetic results in the treatment of hemangiomas with a Nd YAG laser, in contrast to Landthaler et al(1995) They observed superficial scarring in all patients treated by Nd YAG laser. They used an output power of $50 \mathrm{~W}$ with exposure time of up to 1 second. They performed coagulation in four infants (aged 4-months to 14-months) and observed regression of the lesions in three of them. The fourth child, an 11-month-old girl with a pulsating extensive hemangioma of the lower lip, treated with two laser sessions with no effect on the size of hemangioma. . Our results were excellent in most of them. Moreover, we treated an hemangioma similar to the above described hemangioma of the 8-month-old girl in the upper lip with excellent result.

Our results clearly demonstrate the ability of the Nd YAG laser to successfully treat cutaneous hemangiomas of various size. In small and shallow (height $<2 \mathrm{~cm}$, area $<2$ $\mathrm{cm} 2$ ) hemangiomas .We have obtained excellent results . Larger and deeper hemangiomas (height $>2 \mathrm{~cm}$, area $>2 \mathrm{~cm}^{2}$ ) were reduced by approximately 50\% during the first session, , contrasting the results of Clymer et al. (1998) they reported an average of approximately five treatments to achieve the final result .They used interstitial Nd YAG coagulation in eight children with hemangiomas aged 2 months to 8 years. The power settings were between 15 and $25 \mathrm{~W}$, with a pulse length of 0.3 to 1.0 seconds. They observed regression in the size of hemangiomas in all of their patients with good cosmetic results. In our study excellent results ranging from $5^{\text {th }}$ to $12^{\text {th }}$ sessions with an average (8) treatment per patient.

We conclude that use of the Nd:YAG laser is a very useful modality in the treatment of massive and deep hemangiomas in Egyptian infants.

\section{References}

1. Batta K; Goodyear H; Moss C; Williams H. (2002): Hiller L; Waters R. Randomized controlled study of early pulsed dye laser treatment of uncomplicated childhood haemangiomas: Results of 1-year analysis. Lancet. 360:521-527.

2. Boussemart $\mathbf{T}$ Nasimi A., Drouineau J. etal (1995): life. Threatiening haemorrhage from an ulcerated haemangioma: treatment by tramscataneous in- situ sclerosis. Eur $\mathbf{J}$ Pediatr; 124:939-4.

3. Carruther J., jevon G., and prendivillej. (1998): localized dystrophic periocular calcification: a complication of intralesional corticosteroid therapy for infantile periocular hemangiomas. Pediatr Dermatol., 15:23-6.

4. Castro -Ron G. (1985): Cryosurgery of angiomas and birth defects .In: Zacariav S.A, ed. Cryosurgery for skin cancer and cutaneous disorders. St. Louis: Mosby, 7790.

5. Chang CJ; Anvari B; Nelson, JS(1998) . Cryogen spray cooling for spatially selective photocoagulation of hemangiomas: a new methodology with preliminary clinical reports. Plast Reconstr Surg.;102:459-463 .

6. Chang, CJ; Kelly, KM; Van Gemert, MJ; Nelson, JS.( 2002) Comparing the effectiveness of 585-nm vs. 595-nm wavelength pulsed dye laser treatment of port wine stains in conjunction with cryogen Lasers Surg.;31:352-8.

7. Chiller KG, Passero D, Freidan J (2002): Hemangiomas of infancy: Clinical characteristics, morphologic Subtypes and 
their relation ship to race, ethnicity, and Sex. Archives of Dermatology 138: 1567-1576.

8. Clymer M; Fortune S; Reinisch L; Toriumi D; Werkhaven J; Ries R(1998). Interstitial $\mathrm{Nd}$ :YAG photocoagulation for vascular malformations and hemangiomas in childhood. Arch Otolaryngol Head Neck Surg;124:431-436.

9. Esterly N.B (1992): Hemangiomas in infants and Children: Clinical observations. Pediatr Dermatol, 9:353-5.

10. Finn MC, Cilowach : J, Mulliken J. B.(1983) congenital vascular lesions: Clinical application of a new classification. J Pediatr surg; 18:894-9.

11. Kim HJ, Colombo M, frieden IJ. (2001): clinical characteristics and response to therapy. J AM Acad Dermatal; 44:962-72.

12. Kushner B.J. (1990): Infantil orbital hemangiomas. Int Pediatr; 5:249- 57.

13. Landthaler M; Hohenleuther U; ElRaheem TA.(1995): Laser therapy of childhood hemangiomas. Br J Dermatol. 133:275-281.

14. Landthaler M; Hohenleutner U. (2001):
15. Both the flashlamp-pumped dye laser and the long-pulsed tunable dye laser can improve results in port-wine stain therapy. $\mathrm{Br} \mathrm{J}$ Dermatol.;145:79-84. doi: 10.1046/j.13652133.2001.04285.x.

16. Orlow SJ, Isakoff M. s., Blei.F.(1997):Increased risk of symptomatic haemangiomas of the airway in association with cutaneous heamaniomas in a (beard) distrbution .J Pediatr ; 131:643-6.

17. Staindl O. (1989). Treatment of hemangiomas of the face with magnesium seeds. Arch otorhinolaryngol; 246:213-7.

18. Vlachakis I; Gardikis S; Michailoudi E; Charissis, G.(2003): Treatment of hemangiomas in children using a Nd: YAG laser in conjunction with cooling of the epidermis. BMC Pediatr. 3:2-8.

19. Yagupsky P., Gilaldiy. (1987): Group A Bhemolytic streptococcal Speticemia Complicating infected hemangioma in children. Pediate Dermatoly 4:24-6.17 Deans R.M., Harris G.J., and Kivlin J.D. (1992):- Surgical dissection of capillary haemangiormas. Arch ophthamol; 110:17437 . 


\title{
علاج الوحمه الدمويه فى الأطفال بأستخدام جهاز ليزر (Nd-YAG)
}

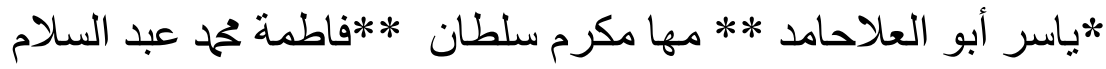

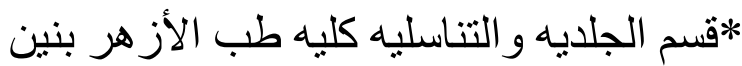

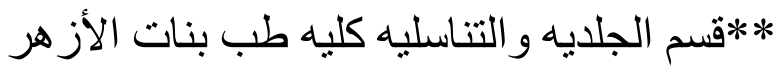

تعد الوحمه الدمويه أكثر العيوب الخلقيه شيو عا فى الأطفال ـ وبالر غم من أنها قد تختفى تلقائيا ألا

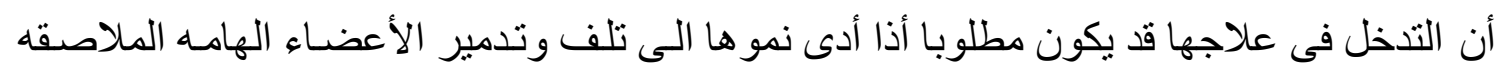

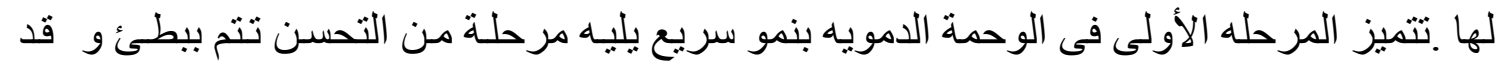

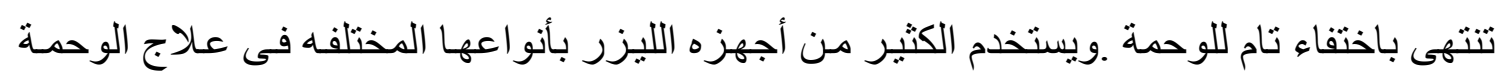

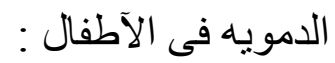
الهدف من هذه الدر اسة هو تحديد كفاءة جهاز (Nd-YAG) ليزر في علاج الوحمة الدمويـه فى

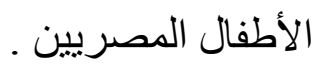

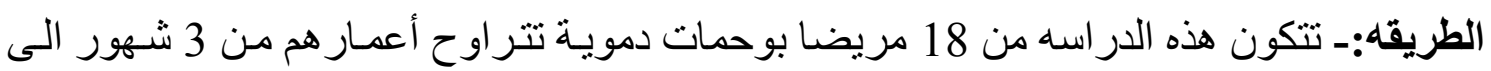

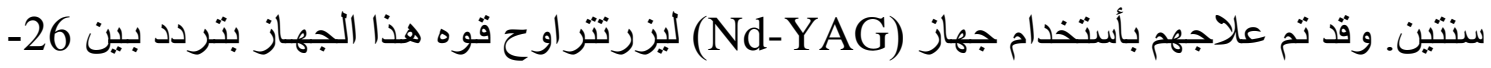
30 جول/ ملى ثانية وطول موجى 50 ملى ثانية وقد تم تبريد الوحمات باستخدام جهاز التبريد لمدة

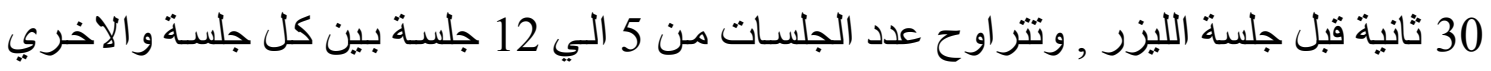

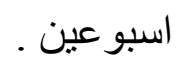

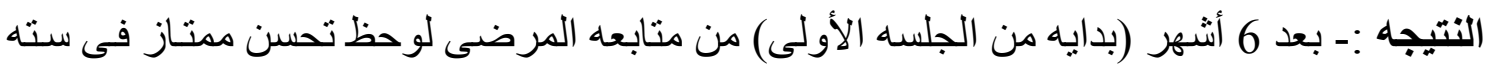

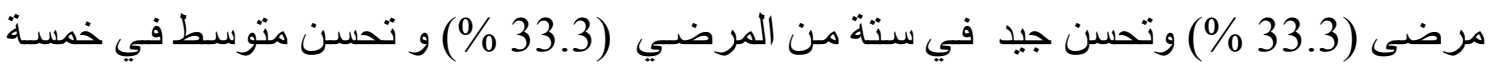

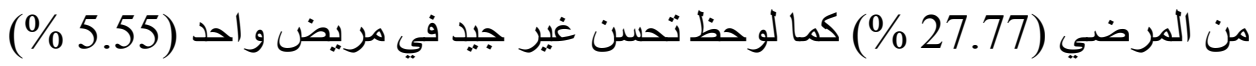
وقد لوحظ أعر اض جانبيه فى ثلاثه من المرضى كنى فقط , كان و احد منهم بنزيف موضعي و واثنان

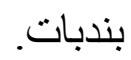
الخلاصة:- تعد نتائج العلاج بجهاز (Nd-YAG) ليزر نتائج تجميليه جيدة فى علاج الوحمـات

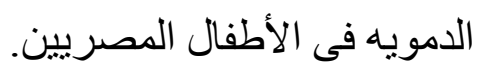

